\title{
FAKTOR YANG BERHUBUNGAN DENGAN PENGELOLAAN SAMPAH RUMAH TANGGA BERBASIS MASYARAKAT DI KAWASAN BANK SAMPAH HANASTY
}

\author{
Despa Wildawati ${ }^{1}$, Evi Hasnita ${ }^{2}$ \\ Sekolah Tinggi Ilmu Kesehatan Fort De Kock Bukittinggi ${ }^{1,2}$ \\ despa.wilda@gmail.com
}

Submitted: 07-08-2019, Reviewer: 13-08-2019, Accepted: 23-10-2019

\begin{abstract}
Urban or settlement waste is one of the problems that needs serious attention because urban or residential waste from year to year continues to increase along with the population growth rate. The purpose of this study was to find out the analysis of community-based solid waste management in the Hanasty Waste Bank area of Tanah Garam Village, Lubuk Sikarah Subdistrict, Solok City in 2019. This type of research was descriptive analytic with crossectional study design. The research sample was 212 respondents in the hanasty waste bank area. To find out the analysis of community-based waste management in the area of the Solok City hanasty waste bank, an analysis was performed with the chi-quare test with a 95\% confidence level. The results showed that after analyzing using the chi-square test, there was a relationship of knowledge (0.014), attitude (0.017) and action (0.039) to community based RT waste management. The government can be used as a reference for making policies on waste management in the city of Solok. And also for the community to increase knowledge and apply experience, also increase awareness in community-based waste management.
\end{abstract}

Keywords: Waste Management, Community, Waste Bank

\begin{abstract}
ABSTRAK
Sampah perkotaan atau pemukiman merupakan salah satu masalah yang perlu mendapat perhatian yang serius karena sampah perkotaan atau pemukiman dari tahun ke tahun terus meningkat seiring dengan laju pertumbuhan jumlah penduduk.Tujuan penelitian ini mengetahui Analisis Pengelolaan Sampah berbasis masyarakat di kawasan Bank Sampah Hanasty Kelurahan Tanah Garam Kecamatan Lubuk Sikarah Kota Solok tahun 2019.Jenis penelitian ini adalah deskriptif analitikdengan desain crossectional study.Sampel penelitian adalah 212 responden di kawasan bank sampah hanasty.Analisis menggunakan uji chis-quare. dengan derajat kepercayaan $95 \%$.Hasil penelitian menunjukkan setelah dilakukan analisis dengan menggunakan uji chi-square diperoleh ada hubungan pengetahuan $(0,014)$, sikap $(0,017)$ dan tindakan $(0,039)$ terhadap pengelolaan sampah RT berbasis masyarakat.Dari penelitian ini dapat disimpulkan bahwa pengangkutan sampah dari sumber ke TPA belum terpisah antara sampah organik dan an organik. Kepada pemerintah dapat dijadikan sebagai acuan untuk pembuatan kebijakan tentang pengelolaan sampah di Kota Solok serta dapat membentuk Lembaga Pengelola Sampah di tingkat RT dan RW dan juga untuk masyarakat dapat menambah pengetahuan serta menerapkan pengalaman, juga meningkatkan kesadaran dalam pengelolaan sampah berbasis masyarakat.
\end{abstract}

Kata kunci: Pengelolaan Sampah, Masyarakat, Bank Sampah

\section{PENDAHULUAN}

Sampah perkotaan atau pemukiman merupakan salah satu masalah yang perlu mendapat perhatian yang serius karena sampah perkotaan atau pemukiman dari tahun ke tahun terus meningkat seiring dengan laju pertumbuhan jumlah 
penduduk.Peningkatan jumlah sampah yang tidak diikuti oleh perbaikan dan peningkatan sarana dan prasarana pengelolaan sampah mengakibatkan permasalahan sampah menjadi lebih serius.Sampah dapat menyebabkan dampak gangguan bagi infrastruktur kota termasuk kerawanan kesehatan dan lingkungan hidup(Santosa,2009).

Hasil penelitian di Srilanka menunjukan bahwa partisipasi masyarakat, kecukupan sumber daya, ketersedian rencana pengelolaan limbah, kesadaran dan pelatihan masyarakat, ketersedian pasar untuk pengomposan, dukungan dari pemerintah, kesadaran akan kebijakan Hukum Nasional, komitmen dan motivasi staf, kontribusi masyarakat dan komunitas bisnis serta remunerasi dan fasilitas staf secara signifikat mempengaruhi keberhasilan program Pengelolaan Limbah Padat Pemda Sri Lanka.

Indonesia merupakan negara dengan penduduk terbanyak ke empat di dunia, dengan total penduduk sebanyak 264 juta . Diperkirakan jumlah penduduk ini akan bertambah menjadi 284,5 juta pada tahun 2025 , dengan jumlah penduduk sebanyak itu diperkirakan akan dihasilkan sampah sebanyak 66,5 juta ton/tahun. Kondisi ini merupakan potensi yang besar sebagai sumberdaya, tetapi saat ini sebagian besar masih menjadi sumber penyebab polusi (Kemen LH, 2014). Kementerian Kesehatan menyatakan bahwa di Indonesia terdapat 240 kota menghadapi masalah pengelolaan sampah (Kemenkes RI, 2013). Kawasan permukiman di perkotaan merupakan produsen sampah terbesar, kira-kira $60-70 \%$ dari total timbulan sampah (Kustiah, 2005).

Undang-undang Nomor 18 tahun 2008 tentang Pengelolaan Sampah menekankan tentang perlunya perubahan pola pengelolaan sampah konvensional menjadi pengelolaan sampah yang bertumpu pada pengurangan dan penanganan sampah. Dalam hal pengurangan sampah, disebutkan dalam pasal 20 meliputi pembatasan timbulan sampah, pendaur ulang sampah, dan atau pemanfaatan kembali sampah atau dikenal dengan 3R (Reduce,Reuse dan Recycle). Hal ini juga dijelaskan dalam Peraturan Pemerintah Republik Indonesia Nomor 81 Tahun 2012 Tentang Pengelolaan Sampah Rumah Tangga dan Sampah sejenis Sampah Rumah tangga. Pengelolaan sampah $3 \mathrm{R}$ berbasis masyarakat merupakan paradigma baru dalam pengelolaan sampah.Paradigma baru tersebut lebih ditekankan kepada metode pengurangan sampah menekankan kepada tingkat perilaku konsumtif dari masyarakat serta kesadaran terhadap kerusakan lingkunngan akibat sampah.Masyarakat menjadi salah satu faktor utama untuk mensukseskan paradigma baru pengelolaan sampah. Program tersebut tidak akan mencapai hasil yang diharapkan tanpa peran serta aktif masyarakat dalam merubah perilaku (Departemen PU, 2008).

Dewasa ini upaya peningkatan kualitas lingkungan telah dilaksanakan oleh sebagian besar pemerintah daerah dan kota di Indonesia melalui pencanangan berbagai program yang relevan. Peningkatan kualitas lingkungan terdiri dari berbagai aspek, salah satu aspek yang sangat berpengaruh adalah aspek pengelolaan sampah di lingkungan permukiman.Persampahan telah menjadi agenda permasalahan utama yang dihadapi oleh hampir seluruh perkotaan di Indonesia. Faktor keberhasilan pelaksanaan pengelolaan sampah sepenuhnya tergantung pada 
kemauan pemerintah daerah atau kota serta masyarakat (Hermawan, 2010).

Saat ini hampir seluruh pengelolaan sampah berakhir di TPA sehingga menyebabkan beban TPA menjadi sangat berat, selain diperlukan lahan yang cukup luas, juga diperlukan fasilitas perlindungan lingkungan yang sangat mahal. Semakin banyaknya jumlah sampah yang dibuang ke TPA salah satunya disebabkan belum dilakukannya upaya pengurangan volume sampah secara sungguh-sunguh sejak dari sumber (Tuti Kustiah : 2005).

Penelitian terdahulu yang telah dilakukan oleh Kelly Daniela dan silva Alcantara Fratta (2018) tentang Diagnosis of the management of solid urban waste of the municipalitis of $A B C$ Paulista of Brasil trhough the application of sustainability.Penelitian ini membahas tantangan dan hambatan yang dihadapi dalam pengelolaan limbah pada perkotaan (MSW) di Kota Madya ABC Paulista. Hasil penelitian menunjukan ada kemajuan berkelanjutan di kota terkait praktek keberlanjutan danmanajemen Pengelolaan Limbah Padat Perkotaan (MSW).

Penelitian lain yang dilakukan oleh Makmur Selomo dkk (2015) di Makassar menyimpulkan bahwa ada hubungan antara tingkat pengetahuan dengan keikut sertaan masyarakat dalam menabung di Bank sampah. Yang mendasari penelitian ini adalah masih rendahnya jumlah masyarakat yang menabung di bank sampah. Penelitian lain yang diulakukan oleh Elvira suryani (2016) tentang Manajemen Pengelolaan Bank Sampah di Kota Bekasi menyimpulkan bahwa penerapan bank sampah belum memperlihatkan hasil yang signifikan hal ini terlihat dari bertambahnya sampah yang diakut ke pembuangan akhir, kesadaran masyarakat masih rendah terhadap pentingnya memilah sampah dari asalnya masih perlu ditumbuhkan terus.

Kota Solok sebagaimana kota lain di Indonesia, jumlah penduduknya juga semakin meningkat dari tahun ke tahun. Berdasarkan data BPS,diketahui bahwa jumlah penduduk Kota Solok pada tahun 2017 sebanyak 67.388 jiwa dan meningkat menjadi 68.648 jiwa pada tahun 2018. Rata-rata pertumbuhan penduduknya sebesar $0,71 \%$ pertahun (BPS Kota Solok , 2017). Meningkatnya jumlah penduduk akan menyebabkan meningkatnya jumlah sampah yang dihasilkan, dimana timbulan sampah rumah permanen adalah 2,25 $\quad-\quad 2,5 \quad$ L/orang/hari sedangkan hasil perhitungan menunjukkan nilai 3,41 L/orang/hari. Hal yang sama juga terjadi pada rumah semi permanen dan non permanen dimana nilai standar antara 2 - 2,25 L/orang/hari dan 1,75 - 2 L/orang/hari, sedangkan hasil pengukuran Kota Solok diperoleh angka 2,91 L/orang/hari (semi permanen)dan 3,38 L/orang/hari (non permanen)(DLH Kota Solok, 2018)

Apabila mengacu pada SNI 193964-1995, maka data diatas menunjukan bahwa jumlah sampah yang dihasilkan oleh masyarakat Kota Solok telah melebihi standar dan hal ini apabila dibiarkan atau tidak dilakukan pengelolaan sampah dengan baik akan menjadi masalah. Sedangkan pengangkutan sampah dilakukan 1 kali dalam sehari pada jam 06.00-07.00 Wib dan tidak semua sampah yang ada di TPS terangkut seluruhnya.(DLH Kota Solok, 2018)

Secara umum kebijakan pengelolaan sampah di Kota Solok masih mengikuti paradigma lama, dimana sampah dikumpulkan, kemudian diangkut dan akhirnya dibuang ke tempat pembuangan akhir (TPA) di Ampang Kualo,Kel. Kampung Jawa. 
Pada sistem tersebut, semakin banyak sampah yang harus dikelola maka biaya yang harus dikeluarkan juga semakin besar.

Upaya strategis yang dilakukan oleh Pemerintah Kota Solok dalam mengatasi persoalan sampah adalah dengan mendorong partisipasi masyarakat dalam pengelolaan sampah dengan melakukan reduksi sampah disumbernya (rumah tangga).Dalam rangka mengimplementasikan kebijakan tersebut, Pemerintah Kota Solok membinaBank Sampah onlinepengelolaan sampah berbasis masyarakat.

Pada saat ini, komunitas pengelola sampah yang dijadikanBank Sampah onlineoleh Pemerintah Kota Solok adalah komunitas pengelola sampah Hanasty. Secara administratif, wilayah ini merupakan wilayah Kel.Tanah Garam, Kec. Lubuk Sikarah. Berdasarkan observasi awal peneliti denganpengelolabanksampahHanasty,m aka terdapat beberapa permasalahan yaitu : Masih kurangnya perhatian pemerintah terhadap pemberdayaan masyarakat tentang pemilahan sampah hal ini dapat dilihat dengan jumlah timbulan sampah yang dibawa ke TPA, masih kurangya SDM yang mengelola bank sampah Hanasty hal ini terlihat dari tidak dapat terlayaninya masyarakat yang telah melakukan pemilahan sampah dan pembiayaan pengelolaan sampah di bank sampahHanasty masih swadaya masyarakat.

Pengkajian mengenai pengelolaan sampah berbasis masyarakat menjadi kajian yang sangat menarik dan strategis, sebagai sebuah upaya untuk mengatasi permasalahan sampah di Kota Solok, terkait dengan jumlah sampah yang semakin meningkat. Hasil dari kajian ini diharapkan dapat menjadi referensi dalam rangka menemukan model yang paling tepat tentang pengelolaan sampah rumah tangga berbasis masyarakat yang dapat diterapkan di perkotaan pada umumnya, dan Kota Solok pada khususnya.

Berdasarkan permasalahan tersebut maka peneliti tertarik melakukan penelitian tentang Analisis Pengelolaan Sampah Berbasis Masyarakat di Kota Solok.

\section{METODE PENELITIAN}

Penelitian ini merupakan jenis penelitian deskriptif analitik dengan menggunakan desain crossectional study. Penelitian ini dilaksanakan pada bulan Juni - Juli di kawasan bank sampah Hanasty Kelurahan Tanah Garam Kecamatan Lubuk Sikarah.Populasi dalam penelitian ini adalah 446 responden dengan sampel 212 responden.Teknik pengambilan sampel dengan menggunakan Purposive sampling.Analisa data menggunakan Univariat dan Bivariat yaitu dengan Uji Chis- Square.Alat ukur menggunakan kuesioner.

\section{HASIL DAN PEMBAHASAN Analisis Univariat}

Pada penelitian ini akan membahas tentang hasil univariat Sesuai dengan hasil penelitian bahwa distribusi frekuensi dapat dilihat pada tabel 1. Pada tabel 1 didapatkan bahwa lebih dari separuh responden yaitu sebanyak 130 responden $(61,3 \%)$ mempunyai pengetahuan tinggi.Lebih dari separuh responden yaitu sebanyak 121 responden $(57,1 \%)$ memiliki sikap yang negatif.Lebih dari separuh responden yaitu sebanyak 115 responden $(54,2 \%)$ sudah melakukan tindakan pengelolaan sampah. 
TABEL 1. DISTRIBUSI FREKUENSI PENGELOLAAN SAMPAH DI KAWASAN HANASTY KELURAHAN TANAH GARAM KOTA SOLOK 2019

\begin{tabular}{ccc}
\hline Pengetahuan & Frekuensi & Persentase (\%) \\
\hline Rendah & 82 & 38,7 \\
Tinggi & 130 & 61,3 \\
\hline Total & 212 & 100,00 \\
\hline Sikap & Frekuensi & Persentase (\%) \\
\hline Negatif & 91 & 42,9 \\
Positif & 121 & 57,1 \\
\hline Total & 212 & 100,00 \\
\hline Tindakan & Frekuensi & Persentase (\%) \\
\hline Tidak Melakukan & 97 & 45,8 \\
Melakukan & 115 & 54,2 \\
\hline Total & 212 & 100,00 \\
\hline Pengelolaan Sampah RT & Frekuensi & Persentase (\%) \\
\hline Tidak melakukan & 73 & 34,4 \\
Melakukan & 139 & 65,6 \\
\hline Total & 212 & 100,00 \\
\hline & &
\end{tabular}

TABEL 2. FAKTOR YANG BERHUBUNGAN DENGAN PENGELOLAAN SAMPAH DI KAWASAN HANASTY|KOTA SOLOK TAHUN 2019

\begin{tabular}{|c|c|c|c|c|c|c|c|c|}
\hline \multirow{3}{*}{ Pengetahuan } & \multicolumn{4}{|c|}{ Pengelolaan Sampah } & & & \multirow{3}{*}{ OR $(95 \% \mathrm{CI})$} & \multirow{3}{*}{ p Value } \\
\hline & \multicolumn{2}{|c|}{$\begin{array}{c}\text { Tidak } \\
\text { Melakuk } \\
\text { an }\end{array}$} & \multicolumn{2}{|c|}{ Melakukan } & \multicolumn{2}{|c|}{ Total } & & \\
\hline & $\mathrm{n}$ & & $\mathrm{n}$ & $\%$ & $\mathrm{~N}$ & $\%$ & & \\
\hline Rendah & 37 & 45,1 & 45 & 54,9 & 82 & 100 & \multirow{3}{*}{$\begin{array}{c}2,147 \\
(1,202-3,836)\end{array}$} & \multirow{3}{*}{0,014} \\
\hline Tinggi & 36 & 27,7 & 94 & 72,3 & 130 & 100 & & \\
\hline Total & 73 & 34,4 & 139 & 65,6 & 212 & 100 & & \\
\hline \multirow{3}{*}{ Sikap } & \multicolumn{4}{|c|}{ Pengelolaan Sampah } & \multirow{2}{*}{\multicolumn{2}{|c|}{ Total }} & \multirow{3}{*}{ OR $(95 \% \mathrm{CI})$} & \multirow{3}{*}{ p Value } \\
\hline & \multicolumn{2}{|c|}{$\begin{array}{c}\text { Tidak } \\
\text { Melakuk } \\
\text { an }\end{array}$} & \multicolumn{2}{|c|}{ Melakukan } & & & & \\
\hline & $\mathrm{n}$ & $\%$ & $\mathrm{n}$ & $\%$ & $\mathrm{~N}$ & $\%$ & & \\
\hline Negatif & 40 & 44 & 51 & 56 & 91 & 100 & \multirow{3}{*}{$\begin{array}{c}2,092 \\
(1,176-3,719)\end{array}$} & \multirow{3}{*}{0,017} \\
\hline Positif & 33 & 27,3 & 88 & 72,7 & 121 & 100 & & \\
\hline Total & 73 & 34,4 & 139 & 65,6 & 212 & 100 & & \\
\hline \multirow{3}{*}{ Tindakan } & \multicolumn{4}{|c|}{ Pengelolaan Sampah } & \multirow{2}{*}{\multicolumn{2}{|c|}{ Total }} & \multirow{3}{*}{ OR $(95 \% \mathrm{CI})$} & \multirow{3}{*}{ p Value } \\
\hline & \multicolumn{2}{|c|}{$\begin{array}{c}\text { Tidak } \\
\text { Melakuk } \\
\text { an }\end{array}$} & \multicolumn{2}{|c|}{ Melakukan } & & & & \\
\hline & $\mathrm{n}$ & $\%$ & $\mathrm{n}$ & $\%$ & $\mathrm{~N}$ & $\%$ & & \\
\hline $\begin{array}{l}\text { Tidak } \\
\text { melakukan }\end{array}$ & 41 & 42,3 & 56 & 57,7 & 97 & 100 & 2.899 & \\
\hline Melakukan & 32 & 27,8 & 83 & 72,2 & 115 & 100 & $(1,070-3,369)$ & 0,039 \\
\hline Total & 73 & 34,4 & 139 & 65,6 & 212 & 100 & & \\
\hline
\end{tabular}

\section{Analisa Bivariat}

Pada analisa bivariat bertujuan untuk melihat hubungan antara variabel independen dan dependen.Dalam penelitian ini peneliti ingin melihat faktor yang berhubungan dengan pengelolaan sampah.Hal ini dapat dilihat pada tabel 2 .

\section{Hubungan Pengetahuan dengan Pengelolaan Sampah}

Berdasarkan tabel2, diperoleh nilai secarastatistikdenganuji $\mathrm{Chi}$ Square yaitup-value $=0,014$. Inimenunjukkanbahwaadahubungan antarapengetahuan dengan pengelolaan sampah.OR didapatkan sebesar 2,147 
artinya bahwa responden yang memiliki pengetahuan rendah berpeluang sebesar 2 kali untuk tidak melakukan pengelolaan sampah dibandingkan dengan responden yang memiliki pengetahuan tinggi.

$$
\text { Menurut World Health }
$$

Organization (WHO) sampah adalah sesuatu yang tidak digunakan, tidak dipakai, tidak disenangi atau sesuatu yang dibuang yang berasal dari kegiatan manusia dan tidak terjadi dengan sendirinya (Chandra, 2005)

Undang-Undang Pengelolaan Sampah Nomor 18 tahun 2008 menyatakan sampah adalah sisa kegiatan seharihari manusia dan/atau dari proses alam yang berbentuk padat.Sampah merupakan suatu benda padat yang tidak dipakai lagi atau sudah tidak dimanfaatkan lagi. Sampah dapat berupa senyawa organik maupun anorganik, yang berupa logam, maupun non logam, berbentuk bahan yang berasal dari mahluk hidup hayati maupun non hayati, oleh yang empunya dianggap tidak diperlukan lagi, kemudian dibuang karena dianggap tidak berguna dan tidak memiliki nilai ekonomi (Sukandarrumidi : 2009).

Penelitian Saputra (2017) di dapatkan $P$-Value $(0,020<0,05$ dengan CI 0,396-1,748) yang berarti bahwa terdapat hubungan pengetahuan dengan perilaku pengelolaan sampah.

Hasil penelitian menunjukkan bahwa sebagian besar masyarakat di kawasan bank sampah Hanasty Kelurahan Tanah Garam Kecamatan Lubuk Sikarah Kota Solok memiliki pengetahuan yang tinggi tentang pengelolaan sampah, pengetahuan yang tinggi ini berpengaruh terhadap perilaku masyarakat. Jika masyarakat di paparkan terus-menerus tentang manfaat pengelolaan sampah serta dampak buruk yang ditimbulkan terhadap kesehatan karena penumpukan sampah maka masyarakat akan tepacu ke depan dalam pengelolaan sampah sehingga sampah yang dihasilkannya bisa terkelola dengan baik dan menjadi nilai ekonomis. Namun masih ada masyarakat yang mempunyai pengetahuan tinggi tapi masih tidak melakukan pengelolaan sampah dengan benar. Hal ini dikarenakan adanya rasa yang tidak peduli terhadap lingkungan sehingga sampah menjadi tidak terkelola dengan baik ,maka dari itu hendaklah petugas kesehatan selalu mendampingi masyarakat dalam mengawasi dan mengelola sampah dengan benar agar sampah terkelola dengan baik dan masyarakat bias hidup sehat.

\section{Hubungan SikapDengan Pengelolaan Sampah}

Berdasarkan tabel2, diperoleh nilai secarastatistikdenganuji $\mathrm{Chi}$ Square yaitup- val u e =0,017. Inimenunjukkanbahwaadahubungan antarasikap dengan pengelolaan sampah.Setelah dilakukan analisis lanjut didapatkan nilai OR sebesar 2,092 artinya bahwa responden yang memiliki sikap negative berpeluang sebesar 2 kali untuk tidak melakukan pengelolaan sampah dibandingkan dengan responden yang memiliki sikap positif.

Sikap adalah reaksi atau respon seseorang yang masih tertutup terhadap suatu stimulasi atau objek, sikap merupakan kesiapan atau kesedian untuk bertindak dan bukan merupakan pelaksana motif tertentu. Sikap belum merupakan suatu tindakan atau aktifita, akan tetapi adalah merupakan predisposisi tindakan atau prilaku. Sikap itu masih merupakan reaksi tertutup, bukan merupakan reaksi terbuka tingkah laku yang tebuka. 
Sikap adalah suatu bentuk evaluasi dan reaksi perasaan (Notoatmojo, 2007)

Penelitian Syam (2016)

menyebutkan bahwa terdapat hubungan sikap masyarakat terhadap pengelolaan sampah di desa Loli Tasiburi Banawa Kabupaten Donggala dengan nilai $P$ Value 0,00 dengan $\alpha 5 \%$.

Berdasarkan asumsi peneliti, hasil penelitian menunjukkan bahwa sebagian besar masyarakat di kawasan bank sampah Hanasty Kelurahan Tanah Garam Kecamatan Lubuk Sikarah Kota Solok memiliki sikap yang positif tentang pengelolaan sampah. Hal ini terlihat dari sikap masyarakat dalam keikutsertaan dalam kegiatan membersihkan sampah di lingkungan mereka, sikap baik ini timbul karena kesadaran masyarakat akan kesehatan karena tumpukantumpukan sampah tersebut bisa menjadi tempat perindukan vektor dan penularan penyakit. Namun masih ada masyarakat yang mempunyai sikap positif tapi masih tidak melakukan pengelolaan sampah dengan baik yang terlihat dari sikap masyarakat yang acuh dalam pengelolaan sampah hal ini dikarenakan kurangnya dukungan keluarga dalam pengelolaan sampah dan kepepedulian terhadap lingkungan, sehingga sampah menjadi tidak terkelola dengan baik, maka dari itu hendaklah petugas kesehatan selalu memberikan contoh sikap yang baik dalam pengelolaan sampah dan bagaimana mengelola sampah yang baik dan benar.

\section{Hubungan \\ Tindakandengan Pengelolaan Sampah}

Berdasarkan tabel2, diperoleh nilai secarastatistikdenganuji $\mathrm{Chi}$ Square $\quad$ yaitup-value $=0,039$. Inimenunjukkanbahwaadahubungan antaratindakan dengan pengelolaan sampah. Didapatkan nilai OR sebesar
2,899 artinya bahwa responden yang tidak melakukan tindakan berpeluang sebesar 3 kali untuk tidak melakukan pengelolaan sampah dibandingkan dengan responden yang melakukan tindakan.

Suatu sikap belum optimis dalam suatu tindakan untuk terwujudnya sikap menjadi suatuperbuatan nyata di perlukan faktor pendukung/ suatu kondisi yang memungkinkan. Menurut Priyoto (2015) tindakan terdiri dari 4 tingkatan yaitu: Presepsi, respon terpimpin, mekanisme dan adopsi. Pada tingkatan Presepsi Mengenal dan memilih berbagai objek sehubungan dengantindakan yang akan diambil adalah merupakan praktek tingkat pertama. Respon terpimpin dapat melakukan sesuai dengan urutan yang benar dan sesuai dengan contoh adalah merupakan indikator praktek tingkat dua.apabila seseorang telah dapat melaksanakan sesuatu dengan benar secara otomatis, atau sesuatu itu sudah merupakan kebiasaan, maka ia sudah mencapai praktek tingkat tiga dan keempat adalah adaptasi, adapsi adalah praktek atau tindakan yang sudah berkembang dengan baik. Artinya itu sudah dimodifikasinya tanpa mengurangi kebenaran tindakan tersebut.

Pengurangan sampah dengan $3 \mathrm{R}$ memang bukan hal mudah untuk dilakukan karena akan sangat bergantung pada kemauan masyarakat dalam merubah perilaku, yaitu dari pola pembuangan sampah konvensional menjadi pola pemilah sampah. Untuk itu diperlukan barbagai upaya baik langsung maupun tidak langsung seperti antara lain, penyuluhan, percontohan program 3R, pemberdayaan dan pendampingan masyarakat dan pendidikan kampanye lingkungan (Departemen PU,2008). 
Hasil ini sesuai dengan penelitian Niken Susanti Maharani (2014) yang ditemukan ada hubungan tindakan ibu rumah tangga dengan pengelolaan sampah rumah tangga dengan nilai $p=0.0001$.

Berdasarkan asumsi peneliti, hasil penelitian menunjukkan bahwa sebagian besar masyarakat di kawasan bank sampah Hanasty Kelurahan Tanah Garam Kecamatan Lubuk Sikarah Kota Solok memiliki tindakan yang baik dalam pengelolaan sampah, hal ini terlihat dari tindakan masyarakat yang sudah memilah sampah organik dan anorganik yang berada di lingkungan rumah tangganya. Jika masyarakat di paparkan terus-menerus tentang manfaat pengelolaan sampah dan pengolahan sampah organik maka penumpukan sampah tidak akan terjadi sehingga masyarakat akan tepacu ke depan dalam pengelolaan sampah dan dapat menjadikan sampah menjadi nilai ekonomis.

Namun masih ada masyarakat yang mempunyai tindakan tinggi tapi masih tidak melakukan pengelolaan sampah dengan baik dan benar. Hal ini dikarenakan adanya rasa yang tidak peduli terhadap lingkungan seperti membuat kerajinan dari barang bekas dan mendaur ulang sampah organik menjadi pupuk kompos sehingga sampah menjadi terkelola dengan baik ,maka dari itu hendaklah petugas kesehatan selalu mendampingi masyarakat dalam mengelola sampah dengan benar dan dapat dipergunakan lagi

\section{KESIMPULAN DAN SARAN}

Hasil observasi menunjukkan bahwa sampah rumah tangga mulai dari masyarakat, dikumpulkan oleh petugas kebersihan di TPS, di proses pengangkutan dari TPS hingga ke TPA terkadang ada proses pemilahan untuk jenis sampah plastik. Sampah basah dan sampah kering masih bercampur menjadi satu.Kondisi fisik kontainer penampungan sampah dan armada pengangkutan sampah juga tidak ada pembagian yang diperuntukkan bagi sampah organik dan anorganik, masih menjadi satu untuk semua jenis sampah. Maka dari itu perlu adanya regulasi dalam pengangkutan sampah agar sampah dapat dikelola menjadi lebih baik lagi.

\section{UCAPAN TERIMA KASIH}

Terima kasih diucapkan kepada STIKes Fort De Kock yang telah memfasilitasi penelitian ini. Selanjutnya, terima kasih juga dihaturkan kepada seluruh responden atas partisipasinya dalam terlaksananya penelitian ini.

\section{DAFTAR PUSTAKA}

Ahmad NurAlamSukrisna Putra, Alia Fajarwati, Kajian Program PengelolaanSampahRumahTanggaM andiri (Bank Sampah) BerbasisMasyarakat Di Kota Yogyakarta

AyuDewantiAnggraini, Irwan Noor, Abdullah Said, StartegiInovatifPengelolaanSampah RumahTanggaPerkotaan, JurnalAdminisrasiPublik (JAP) Vol 3, No. 11

Chandra,B(2005). Pengantar kesehatan Lingkungan. EGC Jakarta

Cahyo, Suryaningsih, Lestari, AnalisisStrategiPengelolaanSampah TerpaduBerbasisMasyarakat Di Kota Semarang

Diana

Hertati,

KebijakanPengelolaanSampahBerba sisMasyarakatSebagaiSolusiAlternati $f$ Green City Di Kota Surabaya

Donna AsterianHeruHeruman (2015), Bank SampahSebagaiAlternatifStrategiPen gelolaanSampahBerbasisMasyarakat Di Tasikmalaya, JurnalManusiadanLingkungan, Vol 23, No. 1, Maret 2016 
Doa, Yosh Christianto dkk, (2016). Hubungan antara pengetahuan dan sikap dengan tindakan ibu rumah tangga dalam pengelolaan sampah rumah tangga di desa borgo kecamatan tombariri kabupaten minahasa. Jurnal IKMAS Vol 1,No7 tahun 2016.

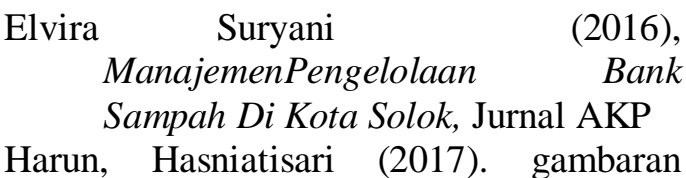
pengetahuan dan perilaku masyarakat dalam proses pemilahan sampah rumah tangga di desa hegarmanah, Jurnal aplikasi IPTEKS untuk masyarakat Vol 6, No 2, Juni 2017:86-88

Hermawan, B. (2010). Determinan Implementasi Program Pengelolaan Sampah Berbasis Masyarakat, Jurnal Upad.

IkaWahyuningWidiarti (2012), PengelolaanSampahBerbasis "Zero Waste"

SkalaRumahTanggaSecaraMandiri, JurnalSainsdanTeknologiLingkungan

Ike Setyaningrum,

KarakteristikPeningkatanPengelolaa nSampahOlehMasyrakatMelului

Bank Sampah, JurnalTeknik PWK Vol 4 Nomor 22015

Indrahati. 2015. Pengaruh Pengetahuan, Sikap Terhadap Perilaku Perawat Dalam Pengelolaan Sampah Medis Dan Non Medis Di Instalasi Rawat Inap Rs. Islam Jemursari Surabaya. Jurnal Keperawatan vol 1 (1).

Kementerian Kesehatan Republik Indonesia, (2013) Road Mam Percepatan Program Sanitasi Total Berbasis Masyarakat.Dit PL Ditjen PP-PL .Jakarta

Kementerian Lingkungan Hidup, (2008) Undang- Undang Republik Indonesia Nomor 18 tahun 2008 Tentang Pengelolaan Sampah, Biro Hukum dan Humas Kementerian Lingkungan Hidup, Jakarta

Kelly Danielly da Silva Alcantara Fratta, dkk (2018). Diagnosis of Solid Urban Waste of the Municipalities of
$A B C$ Paulista of Brasil through the Application of Sustainability.

Karlita Ayu S(2018). Kajian Pengelolaan Sampah Berbasis Masyarakat di Kawasan Perkotaan Ciwidey. Tesis Program Studi Perencanaan Wilayah dan Kota Fakultas Tekni Universitas Pasudan, Bandung

Lemeshow, Stanley (1997) Besar Sampel Dalam Penelitian Kesehatan. Gajah Mada University Press

Notoatmodjo,Soekidjo.(2007). Promosi Kesehatan dan Ilmu Perilaku. Penerbit Rineka Cipta Jakarta

Sari, Nova, Surahma Asti Mulasari, (2017). Pengetahuan, sikap dan pendidikan dengan perilaku pengelolaan sampah di Kelurahan Bener Kecamatan Tegalrejo Yogyakarta. Jurnal medika respati Vol, 12 No 2 April.

Saputra N.A, Sangga, Mulasari surahma asti, (2017). Pengetahuan, sikap dan tindakan pengelolaan sampah pada karyawan di kampus.Jurnal fakultas kesehatan masyarakat Vol 11, issue, Maret 2017, pp 22-27.

Sukandar rumidi. (2009) Rekasaya Gambut,Briket Batubara dan Sampah Organik Usaha Memanfaatkan Sumber Daya Alam yang Terpinggirkan. Gadjah Mada University Press. Yogyakarta

Santosa,Afit (2009). Co-Management, Pendekatan Pengelolaan Sampah.Neliti.com diakses pada 12 Desember 2018 pukul 15 : 28 WIB

Soemirat ( 2014).Kesehatan Lingkungan Gadjah Mada University Press. Yogyakarta

Sutarto.(2004) Implementasi Kebijakan Persampahan di Kota Semarang.Tesis S-2. Pasca Sarjana Universitas Diponegoro. Semarang

Srisantyorini, Triana, Febriana Kusuma Ningtyas, (2018). Pengetahuan, sikap dan perilaku ibu rumah tangga terhadap pengelolaan sampah di wilayah sekitar rel kereta api Kelurahan Jombang Kecamatan Ciputat Kota Tangerang Selatan. Jurnal kedokteran dan kesehatan Vol, 14 No,2 Juli 2018. 
Syam, Dedi Mahyudin, (2016). Hubungan pengetahuan dan sikap masyarakat dengan pengelolaan sampah di desa loli tasiburi kecamatan banawa kabupaten donggala.Jurnal kesehatan lingkungan poltekkes palu volume 2 No 1 Januari-April. 2016.

Syafrudin. (2006) BukuAjar Pengelolaan Limbah Padat ( Sampah) Perkotaan Program Studi Teknik Lingkungan, Fakultas Teknik Undip, Semarang
TatiRuhmawati,

MiminKarmini, DwiTjahjani (2017), Peningkatan PengetahuandanSikapKepalaKeluar ga di KelurahanTarmansari Kota Bandung, JurnalKesehatanLingkungan Indonesia, 2017

TikaFaristaCandra, PambudiHandoyo (2014),

StrategiPemberdayaanMasyarakatD alamPraktek Bank Sampah, ParadigmaVol 2 Nomor 2 Tahun 2014 